Arkivoc

Archive for

Organic Chemistry
The Free Internet Journal

for Organic Chemistry
Paper

Arkivoc 2017, part iii, 166-180

\title{
Electrochemical reduction, radical anions, and dehalogenation of fluorinated/chlorinated 2,1,3-benzothia/selenadiazoles
}

\author{
Leonid A. Shundrin, ${ }^{\text {a,b }}$ Irina G. Irtegova, ${ }^{a}$ Pavel A. Avrorov, ${ }^{a}$ Tatiana F. Mikhailovskaya, ${ }^{a}$ Arkady G. \\ Makarov, ${ }^{a}$ Alexander Yu. Makarov, ${ }^{a}$ and Andrey V. Zibarev*a,c \\ aInstitute of Organic Chemistry, Russian Academy of Sciences, 630090 Novosibirsk, Russia \\ ${ }^{b}$ Department of Natural Sciences, National Research University - Novosibirsk State University, 630090 \\ Novosibirsk, Russia \\ 'Department of Chemistry, National Research University - Tomsk State University, 634050 Tomsk, Russia \\ E-mail: zibarev@nioch.nsc.ru, shundrin@nioch.nsc.ru
}

\section{Dedicated to Prof. Oleg A. Rakitin on the occasion of his 65th birthday}

Received 03-27-2017

Accepted 05-01-2017

Published on line 06-25-2017

\section{Abstract}

At the first stage of electrochemical reduction in DMF, fluorinated/chlorinated 2,1,3-benzothia/selenadiazoles formed long-lived radical anions characterized by EPR and DFT. Gas-phase electron affinities (EA 1 ) from DFT correlated well with the first-peak potentials separately for $S$ and Se derivatives, and the latter were found to be better electron acceptors than the former in contrast to the atomic $E A_{1}$ and Allen electronegativity. At the second stage, chalcogen- and halogen-dependent dehalogenation proceeded: non-hydrodefluorination of selenadiazoles through their $n$-electron activation $(n \geq 2)$, and hydrodechlorination of thia/selenadiazoles through $\mathrm{H}^{+}$addition to their dianions. These differ from dehalogenation of related (aza) aromatics (e.g. benzenes, naphthalenes, quinoxalines).

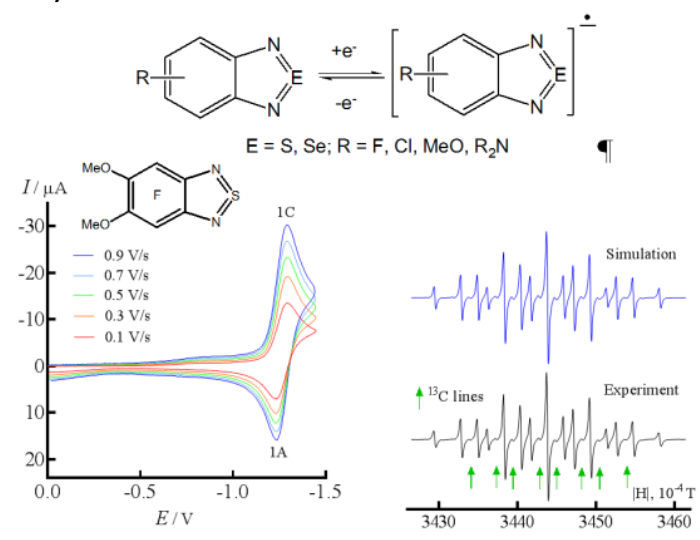

Keywords: 2,1,3-Benzothiadiazoles, 2,1,3-benzoselenadiazoles, chlorinated, cyclic voltammetry, dehalogenation, DFT, EPR, fluorinated, radical anions 


\section{Introduction}

2,1,3-Benzothia/selenadiazoles are redox-active $10 \pi$-electron heteroaromatics - chalcogen-nitrogen analogs of naphthalene and chalcogen analogs of quinoxaline. ${ }^{1,2}$ Their chemistry is well-studied (for selected works, see refs. 3-10 and references therein). Similar to many other chalcogen-nitrogen $\pi$-heterocycles, they possess positive electron affinity (EA) making them effective electron acceptors ${ }^{3}$ - precursors of stable radical anions (RAs) isolated in the form of salts and characterized by X-ray diffraction. ${ }^{11,12}$ Also, they are luminophores. For these reasons, 2,1,3-benzothia/selenadiazoles found numerous applications as electron-acceptor or/and luminescent building blocks of real or potential molecular functional materials for electronics, optoelectronics and photovoltaics. ${ }^{4,5,13-25}$ Despite fluorinated (hetero) aromatics are promising for electronic and optoelectronic applications, ${ }^{26,27}$ fluorinated 2,1,3-benzothia/selenadiazoles are less studied in this context.

Hydrogen replacement by fluorine affects many properties of (hetero) aromatics including (hetero) aromaticity itself. ${ }^{28}$ Particularly, it enlarges $\mathrm{EA}_{1}$ of 2,1,3-benzothia/selenadiazoles, ${ }^{2,3}$ i.e. their electron-acceptor ability, which can be used in the design of functional materials. Recently, our group suggested unified synthetic approach to fluorinated 2,1,3-benzothia/selenadiazoles. ${ }^{29,30}$ Since redox properties of compounds are of general significance for organic chemistry and its applications, ${ }^{31}$ in this work we report on electrochemical reduction (ECR) of new fluorinated 2,1,3-benzothia/selenadiazoles bearing also chlorine and some other substituents (120, Figure 1), studied by cyclic voltammetry (CV), as well as on their persistent RAs characterized by EPR spectroscopy and DFT calculations. Compounds $\mathbf{3}$ and $\mathbf{1 2}$ together with their RAs have been characterized earlier ${ }^{2}$ as well as related fluorinated 1,4-benzodiazines (quinoxalines) and their RAs. ${ }^{32}$ For some derivatives, chalcogen- and halogen-dependent dehalogenation was observed being of special chemical interest.
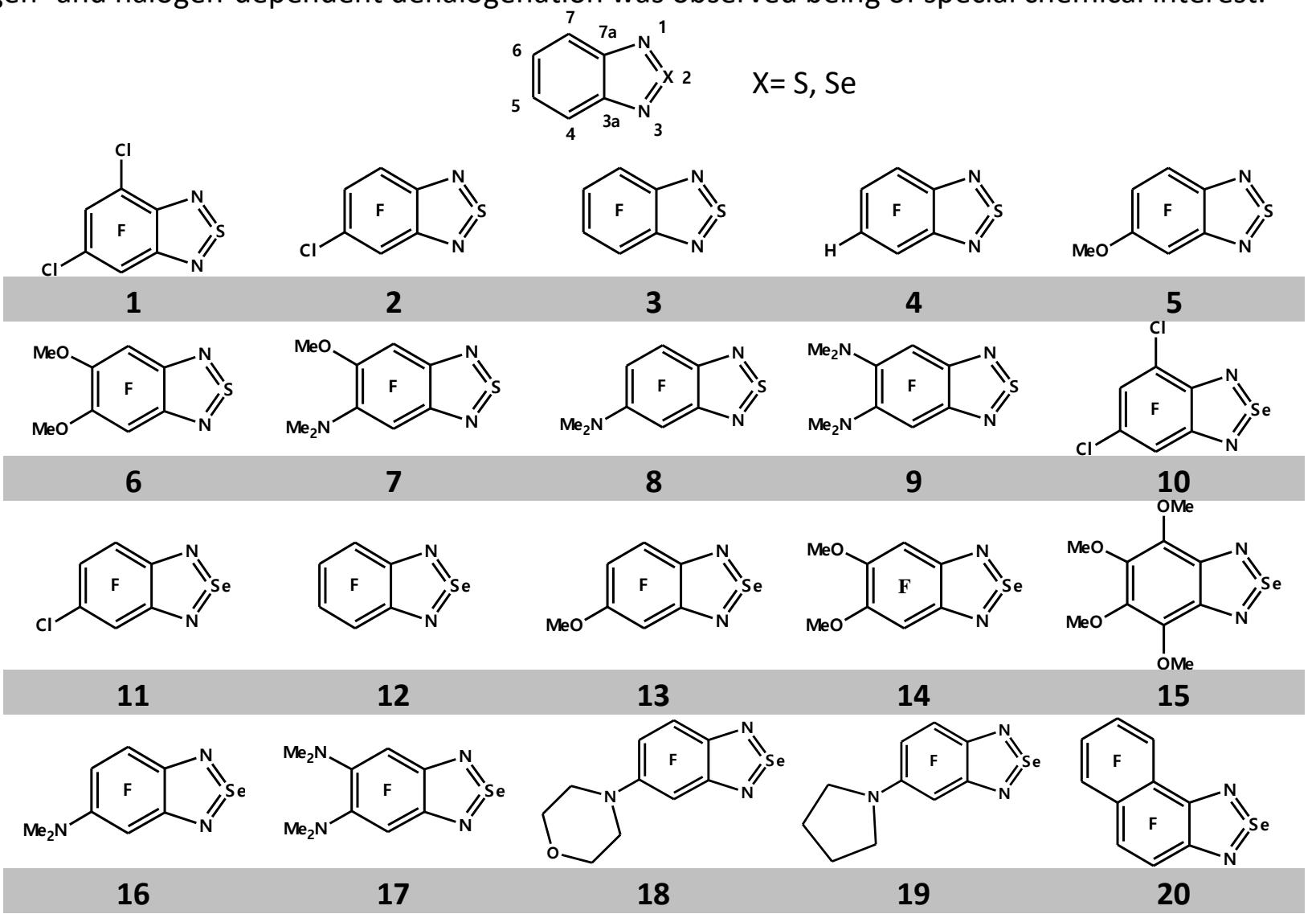

Figure 1. Compounds and atom numbering.

\section{Results and Discussion}


Electrochemical reduction and dehalogenation. Most of the studied compounds are known ones. ${ }^{29,30}$ Derivatives 1, 2 and 4-9 were prepared by nucleophilic substitution of fluorine in 4,5,6,7-tetrafluoro-2,1,3benzothiadizole 3, and 10, 11 and 13-19 in 4,5,6,7-tetrafluoro-2,1,3-benzoselenadiazole 12. ECR peak potentials, CVs and some transformations of 1-20 under ECR in DMF in the potential range $0>E>-2.2 \mathrm{~V}$ (vs. saturated calomel electrode, SCE) are represented in Table 1, Figures 2 and 3 (ESI: Figures S1 and S2, Table S1), and Schemes 1 and 2; for ECR of $\mathbf{3}$ in MeCN, see ref. 2. In $E_{\mathrm{p}}^{i j}$ designation of peak potentials, $i$ is a number of peak and $j=C$ or $A$ indicates a cathode or an anode branches of CVs; designation of peak currents is the same.

Table 1. ECR peak potentials $E_{\mathrm{p}}^{i \mathrm{C}}(\mathrm{V})$ in $\mathrm{DMF}^{\mathrm{a}}$ and gas-phase $\mathrm{EA}_{1}(\mathrm{eV})^{\mathrm{b}}$ of compounds 1-20

\begin{tabular}{lcccccccc}
\hline Compound & & $\mathbf{1}$ & $\mathbf{2}$ & $\mathbf{3}$ & $\mathbf{4}$ & $\mathbf{5}$ & $\mathbf{6}$ & $\mathbf{7}$ \\
$E_{\mathrm{p}}^{i \mathrm{C}}$ & $i=1$ & -1.00 & -1.02 & $-1.11^{c}$ & -1.12 & -1.20 & -1.30 & -1.34 \\
& $i=2$ & -1.94 & -2.01 & & -2.27 & $\sim-2.4$ & & \\
& $i=3$ & -2.19 & & & & & & \\
$\mathrm{EA}_{1}$ & & 1.67 & 1.63 & 1.57 & 1.57 & 1.36 & 1.16 & 1.07 \\
\hline Compound & & $\mathbf{8}$ & $\mathbf{9}$ & $\mathbf{1 0}$ & $\mathbf{1 1}$ & $\mathbf{1 2}$ & $\mathbf{1 3}$ & $\mathbf{1 4}$ \\
$E_{\mathrm{p}}^{i \mathrm{C}}$ & $i=1$ & -1.26 & -1.39 & -0.91 & -0.94 & -0.98 & -1.08 & -1.18 \\
& $i=2$ & & & -1.71 & -1.78 & -1.97 & -2.17 & -2.20 \\
& $i=3$ & & & $-2.00^{d}$ & -2.03 & -2.05 & & \\
$\mathrm{EA}_{1}$ & & 1.28 & 1.01 & 1.81 & 1.78 & 1.72 & 1.55 & 1.30 \\
\hline Compound $_{i}$ & & 15 & 16 & 17 & 18 & 19 & $\mathbf{2 0}$ & \\
$E_{\mathrm{p}}^{i \mathrm{C}}$ & $i=1$ & -1.38 & -1.13 & -1.28 & $-1.10^{e}$ & -1.20 & -1.08 & \\
& $i=2$ & -2.30 & & -2.14 & -2.06 & -1.80 & -1.09 & \\
EA $_{1}$ & $i=3$ & & & & & -2.07 & -2.00 & \\
\hline
\end{tabular}

a Measured with $v=0.1 \mathrm{~V} \cdot \mathrm{s}^{-1}$. ${ }^{\mathrm{b}}$ The first adiabatic EA calculated at the $(U) B 3 L Y P / 6-31+G(d)$ level of theory.

${ }^{\mathrm{c}}$ Recalculated from the data of ref. 2: $E_{\mathrm{p}}^{1 \mathrm{C}}(\mathrm{DMF})=E_{\mathrm{p}}^{1 \mathrm{C}}(\mathrm{MeCN})+0.1(\mathrm{~V}) \cdot{ }^{\mathrm{d}}$ An additional peak was observed at $E_{\mathrm{p}}^{4 \mathrm{C}}=-2.08 \mathrm{~V}\left(\mathrm{ESI}\right.$, Figure S2). ${ }^{e} \mathrm{ESI}$, Figure S2.

The first stage of the ECR of thiadiazoles 1-9 is one-electron transfer forming long-lived RAs characterized by EPR (see below). It features reversible and diffusion-controlled peaks in the $\mathrm{CVs}\left(I_{\mathrm{p}}^{1 \mathrm{C}} \cdot \mathrm{v}^{-1 / 2}=\right.$ const; ESI: Figures S1 and S2, Table S1). The ECR of 2 (Figure 2) is characterized by two peaks $1 \mathrm{C}$ and $2 \mathrm{C}$ at the first cycle of the CV, $0>E>-2.2 \mathrm{~V}$, the first of which is one-electron and reversible; no additional peaks were observed in the range $0>E>-1.5 \mathrm{~V}$ covering the first step of the ECR only. The irreversible one-electron peak $2 \mathrm{C}$ corresponds to the formation of unstable dianion (DA) which can undergo an addition of two $\mathrm{H}^{+}$to $\mathrm{N}$ atoms (cf. ref. 33) or one $\mathrm{H}^{+}$ to the carbocycle with subsequent hydrodechlorination. For $\mathbf{2}$, the latter process seems to be slow because the reversible peaks $3 \mathrm{C}$ and $3 \mathrm{~A}\left(E_{\mathrm{p}}^{3 \mathrm{C}}=-1.12, E_{\mathrm{p}}^{3 \mathrm{~A}}=-1.07 \mathrm{~V}\right)$ corresponding to the formation of the $\mathrm{RA}$ of hydrodechlorinated product 4 (detected by EPR) were observed at the second and subsequent potential sweep cycles only with $v>0.3 \mathrm{~V} \cdot \mathrm{s}^{-1}$ in the range $0>\mathrm{E}>-2.2 \mathrm{~V}$ (Figure 2). The ECR of 1 is similar except that an additional peak 3C was observed (Table 1; ESI: Figure S2). Overall, in interesting contrast to related quinoxalines whose 
hydrodechlorination proceeds via RAs, ${ }^{32}$ that of studied thiadiazoles involves DAs and their protonation (Scheme 1).


Figure 2. $C V$ of 2 in $D M F$ in the potential ranges $0>E>-2.2 \mathrm{~V}$ (left) and $0>E>-1.5 \mathrm{~V}$ (right) at different sweep rates indicated by color.



Scheme 1. Two-electron ECR hydrodechlorination of $\mathbf{2}$ followed by one-electron ECR of its product 4.

Similarly, peak $1 \mathrm{C}$ of selenadiazoles $\mathbf{1 0 - 2 0}$ (Table 1 ) is one-electron, diffusion-controlled and reversible, i.e. corresponding to the formation of long-lived RAs (for 11 and 12, see Figure 3; for the other, ESI: Figures S1 and S2, Table S1). Peaks $2 C$ and $3 C$, however, are essentially irreversible for all 10-20, and peak $2 C$ is more than oneelectron ( $I_{\mathrm{p}}^{2 \mathrm{C}} / I_{\mathrm{p}}^{1 \mathrm{C}}>1$, Figure 3; ESI, Figure S2).

For 12 in the range $0>\mathrm{E}>-2.2 \mathrm{~V}$, reversible one-electron peaks $4 \mathrm{C}$ and $4 \mathrm{~A}\left(E_{\mathrm{p}}^{4 \mathrm{C}}=-1.45, E_{\mathrm{p}}^{4 \mathrm{~A}}=-1.39 \mathrm{~V}\right)$ were observed at the second cycle of potential sweep, whereas no additional peaks were detected in the range $0>E>-1.7 \mathrm{~V}$ (Figure 3). The peaks were attributed to one-electron ECR of the product resulted from defluorination of 12. Importantly, no additional peaks in the second sweep cycle in the range $E_{\mathrm{p}}^{2 \mathrm{C}}<E<E_{\mathrm{p}}^{1 \mathrm{C}}$ were detected for 14-17 with non-halogen substituents in the positions 5 and 6, whereas weak ones were observed in anode branches of the CVs of 13, 18 and 19 with $\mathrm{F}$ atoms in the position 6 (ESI: Figure S2). Altogether, these suggest that defluorination of 12 occurs regioselectively at equivalent positions 5 / 6 not involving the positions 4 / 7 (note that in fluorinated selenadiazoles the positions 5 and 6 are much more active in nucleophilic substitution than the positions 4 and 7). ${ }^{29}$ This is, however, only minor process because peaks $4 \mathrm{C}$ and $4 \mathrm{~A}$ are characterized by substantially lower currents as compared with the first peaks in CVs (Figure 3). 

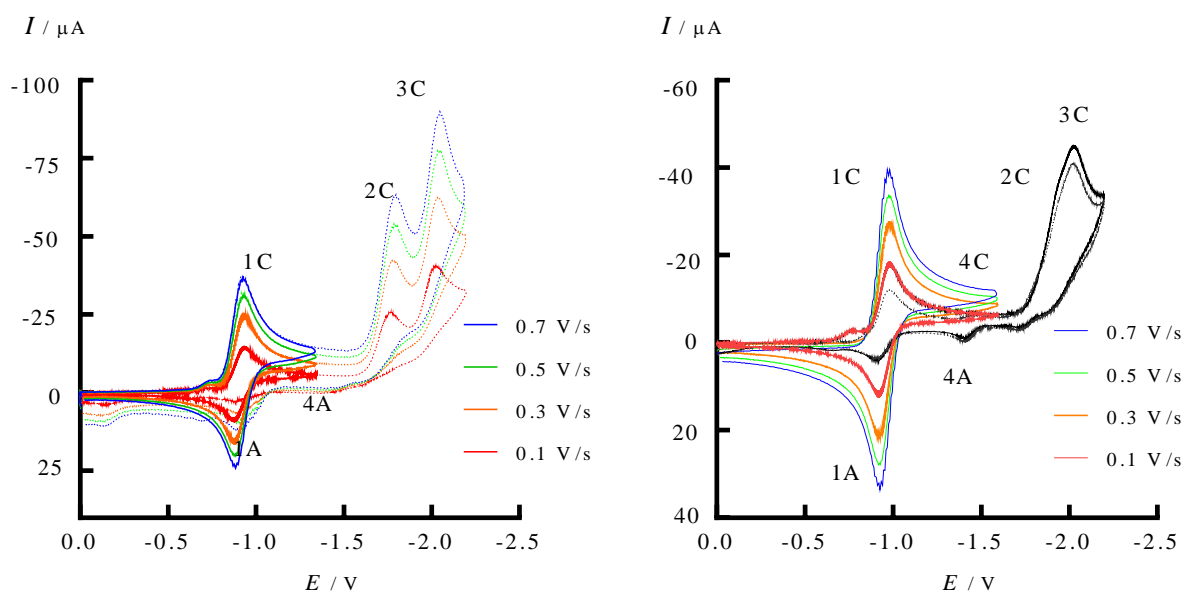

Figure 3. Left: $C V$ s of 11 in the potential ranges $0>E>-1.5 \vee$ (solid lines) and $0>E>-2.2 \vee$ (dotted lines) at different sweep rates indicated by color. Right: $C V$ of 12 in the potential ranges $0>E>-1.7 \vee$ at different sweep rates, and $0>E>-2.2 \mathrm{~V}$ at $100 \mathrm{mV} \cdot \mathrm{s}^{-1}$ (black solid and dotted lines correspond to the first and second cycles, respectively).

Under conditions of stationary electrolysis of 12 at the $E_{\mathrm{p}}^{2 \mathrm{C}}$ potential, a RA was detected whose EPR hyperfine splitting (hfs) featured two nuclei with spin 1 and three with spin $1 / 2$ thus indicating the absence of either $\mathrm{H}$ or $\mathrm{F}$ atom in the position 5/6. As compared with EPR spectra of RAs of 1-20 in DMF at T= $295 \mathrm{~K}$ (below), the spectrum of this RA revealed broadened high-field lines in nitrogen hfs suggesting modulation of ${ }^{14} \mathrm{~N}$ anisotropic hyperfine interaction caused by its slower rotational diffusion. The latter can be associated with the presence of a multi-atom substituent $\mathrm{R}$ in the position 5/6 of the RA. The nature of $\mathrm{R}$ is unclear, it is not $\mathrm{HO}$ or $\mathrm{Me}_{2} \mathrm{~N}$ Special experiments shown that with $\mathrm{HO}^{-}$(e.g. originated from protonation of DA of 12 by $\mathrm{H}_{2} \mathrm{O} ; c f$. ref. 33) nucleophilic substitution in $\mathbf{1 2}$ does not proceed even under much drastic conditions; with $\mathrm{Me}_{2} \mathrm{NH}$ (from decomposition of DMF under basic conditions), RA of $\mathbf{1 6}$ should be seen with EPR. Therefore, only structure $\mathbf{2 1}$ can be assigned to the discussed RA in tentative explanation of the chemistry observed (Scheme 2) requiring further investigation. In any way, one can conclude that ECR defluorination of $\mathbf{1 2}$ differs from that of its $S$ congener 3 proceeded as hydrodefluorination. ${ }^{2}$
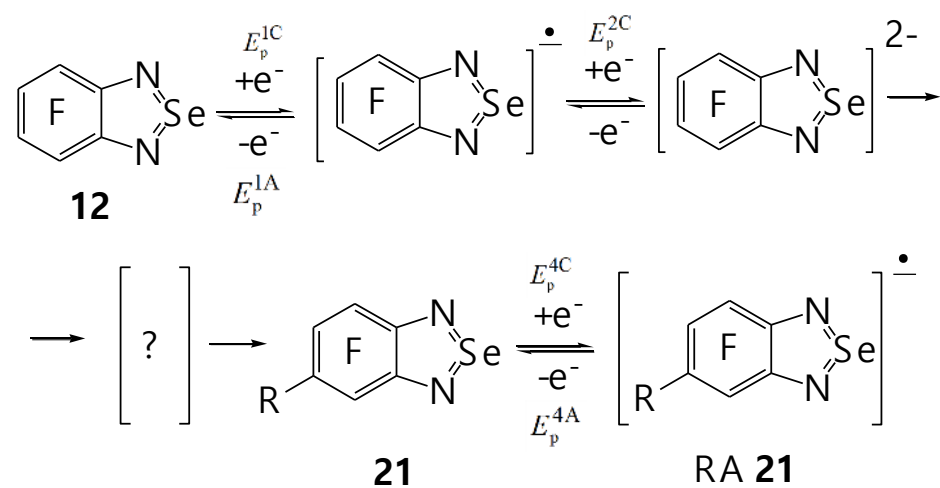

Scheme 2. Tentative explanation of defluorination of $\mathbf{1 2}$ with the formation of $\mathbf{2 1}$ followed by its one-electron reduction; $\mathrm{R} \neq \mathrm{H}, \mathrm{F}, \mathrm{HO}, \mathrm{Me}_{2} \mathrm{~N}$. 
First electrochemical potentials and gas-phase electron affinities. The $E_{\mathrm{p}}^{1 \mathrm{C}}$ values of selenadiazoles are $c a$. 0.1 $\pm 0.03 \mathrm{~V}$ less negative, and $\mathrm{EA}_{1} \mathrm{ca} .0 .17 \mathrm{eV}$ more positive, than those of thiadiazoles with the same substitution patterns (Table 1, pairs 1/10, 2/11, 3/12, 5/13, 6/14, 8/16 and 9/17). They form two independent linear regressions $\mathrm{EA}_{1}=a E_{\mathrm{p}}^{1 \mathrm{C}}+b$ (Figure 4) with $a, b$ and $r^{2}$ equal to $1.79 \mathrm{eV} \cdot \mathrm{V}^{-1}, 3.50 \mathrm{eV}$ and 0.972 , respectively, for thiadiazoles 1-9; and to $1.61 \mathrm{eV} \cdot \mathrm{V}^{-1}, 3.30 \mathrm{eV}$ and 0.948 for selenadiazoles 10-19; $r$ is correlation coefficient. The values of $a$ and $b$ for both regressions are comparable with those for related compounds whose $E_{\mathrm{p}}^{1 \mathrm{C}}$ were measured in $\mathrm{MeCN} .^{2}$
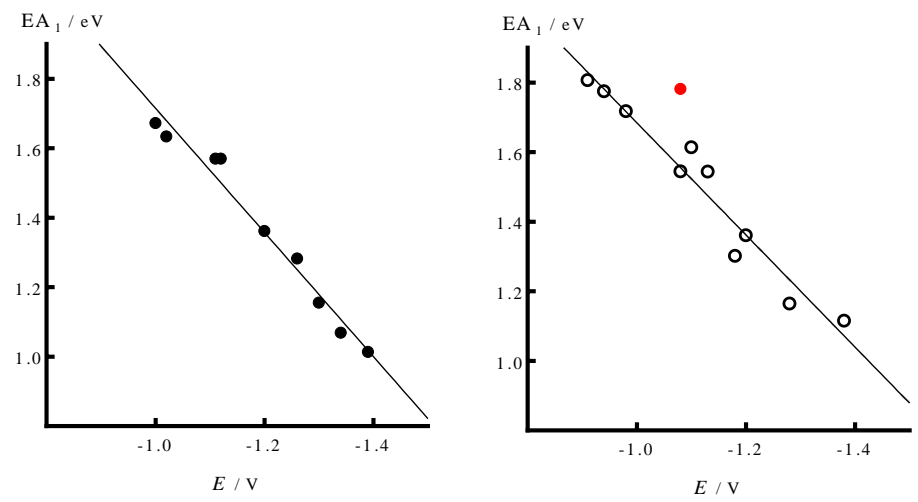

Figure 4. Correlation between $\mathrm{EA}_{1}$ and $E_{\mathrm{p}}^{1 \mathrm{C}}$ for thiadiazoles 1-9 (left) and selenadiazoles 10-19 (right); 20 (red point) is not included due to another scaffold topology.

Altogether, these findings indicate that, in spite of lesser atomic $\mathrm{EA}_{1}$ and Allen electronegativity of Se (2.02 and 2.42) vs. S (2.08 and 2.59), selenadiazoles are better electron acceptors than their $S$ congeners. Earlier, this property was pointed with B3LYP calculations, and with MP2 ones it was shown that the result is not an artifact of the DFT approach. ${ }^{3}$ Now this non-trivial trend (covering also Te congeners of compounds under discussion) ${ }^{3}$ received experimental electrochemical confirmation. Tentatively, it might be explained by better charge/spin delocalization in the RAs of Se derivatives caused by more diffuse $4 p-A O$ of Se as compared with 3p-AO of S.

For compounds with electron-donating substituents $\mathrm{MeO}$ and $\mathrm{Me}_{2} \mathrm{~N}, E_{\mathrm{p}}^{1 \mathrm{C}}$ and $E A_{1}$ values reveal additivity under their accumulation. Thus, for MeO-substituted thiadiazoles 5 and $\mathbf{6}$, the negative shifts of the $E_{\mathrm{p}}^{1 \mathrm{C}}$ relative to that of the parent 3 are -0.09 (one $\mathrm{MeO}$ ) and $-0.19 \mathrm{~V}$ (two $\mathrm{MeO}$ ), respectively; for $\mathrm{Me}_{2} \mathrm{~N}$-substituted thiadiazoles 8 and 9 the corresponding shifts are -0.15 and $-0.28 \mathrm{~V}$ (Table 1). For selenadiazoles, the additivity of such shifts is more exact to be $-0.10,-0.20,-0.40 \mathrm{~V}$ for MeO-substituted 13, 14 and 15 in relation to $E_{\mathrm{p}}^{1 \mathrm{C}}$ of the parent 12; and -0.15 and $-0.30 \mathrm{~V}$ for $\mathrm{Me}_{2} \mathrm{~N}$-substituted 16 and 17 (Table 1). Previously, the additivity of $E_{\mathrm{p}}^{1 \mathrm{C}}$ was observed for benzenes and naphthalenes on accumulation of electron-withdrawing substituents $\mathrm{CF}_{3} .{ }^{34} \mathrm{The}$ present work, therefore, generalizes the trend.

EPR of radical anions. The EPR and DFT data of ECR generated (DMF, $295 \mathrm{~K}$ ) RAs 1-21 are represented in Table 2 and Figs. 5 and 6; the EPR spectrum of product of ECR of $\mathbf{3}$ in MeCN was reported earlier. ${ }^{2}$ Experimental and DFT-calculated isotropic hyperfine coupling (hfc) constants are in reasonable agreement.

Table 2. Experimental in DMF and gas-phase DFT-calculated isotropic hfc constants (G) of RAs 1-21 ${ }^{\text {a }}$ 


\begin{tabular}{|c|c|c|}
\hline RA & Experiment & (U)B3LYP/6-31+G(d) \\
\hline 1 & $\begin{array}{c}4.30\left(\mathrm{~N}^{1}\right), 5.56\left(\mathrm{~N}^{3}\right), 6.92\left(\mathrm{~F}^{4}\right), 3.62\left(\mathrm{~F}^{6}\right), \sim 0.09 \\
\left(\mathrm{Cl}^{5}\right), \sim 0.18\left(\mathrm{Cl}^{7}\right)\end{array}$ & $4.60\left(N^{1}\right), 6.06\left(N^{3}\right), 8.02\left(F^{4}\right), 2.61\left(F^{6}\right)$ \\
\hline 2 & $\begin{array}{c}4.80\left(\mathrm{~N}^{1}\right), 5.65\left(\mathrm{~N}^{3}\right), 5.41\left(\mathrm{~F}^{4}\right), 2.86\left(\mathrm{~F}^{6}\right), 4.19\left(\mathrm{~F}^{7}\right) \\
\sim 0.19\left(\mathrm{Cl}^{5}\right)\end{array}$ & $5.20\left(N^{1}\right), 6.16\left(N^{3}\right), 6.48\left(F^{4}\right), 1.26\left(F^{6}\right), 4.70\left(F^{7}\right)$ \\
\hline $3^{b}$ & $5.46\left(\mathrm{~N}^{1,3}\right), 4.82\left(\mathrm{~F}^{4,7}\right), 4.78\left(\mathrm{~F}^{5,6}\right)$ & $5.75\left(N^{1,3}\right), 5.04\left(F^{4,7}\right), 2.49\left(F^{5,6}\right)$ \\
\hline 4 & $\begin{aligned} 4.81\left(\mathrm{~N}^{1}\right), 5.97\left(\mathrm{~N}^{3}\right), & 4.25\left(\mathrm{~F}^{4}\right), 1.54\left(\mathrm{H}^{5}\right), 2.67\left(\mathrm{~F}^{6}\right) \\
& 3.20\left(\mathrm{~F}^{7}\right)\end{aligned}$ & $\begin{array}{c}5.10\left(\mathrm{~N}^{1}\right), 6.45\left(\mathrm{~N}^{3}\right), 5.85\left(\mathrm{~F}^{4}\right),-1.71\left(\mathrm{H}^{5}\right), 1.69\left(\mathrm{~F}^{6}\right), \\
4.02\left(\mathrm{~F}^{7}\right)\end{array}$ \\
\hline 5 & $5.28\left(\mathrm{~N}^{1}\right), 5.52\left(\mathrm{~N}^{3}\right), 4.06\left(\mathrm{~F}^{4}\right), 3.86\left(\mathrm{~F}^{6}\right), 4.06\left(\mathrm{~F}^{7}\right)$ & $5.49\left(N^{1}\right), 6.03\left(N^{3}\right), 5.25\left(F^{4}\right), 2.14\left(F^{6}\right), 4.47\left(F^{7}\right)$ \\
\hline 6 & $5.47\left(N^{1,3}\right), 3.37\left(F^{4,7}\right), 2.05\left({ }^{13} C^{3 a, 7 a}\right), 2.03\left({ }^{13} C^{4,7}\right)$ & $5.74\left(N^{1,3}\right), 4.69\left(F^{4,7}\right),-5.14\left({ }^{13} C^{3 a, 7 a}\right), 5.07\left({ }^{13} C^{4,7}\right)$ \\
\hline 7 & $\begin{array}{c}5.29\left(\mathrm{~N}^{1}\right), 5.65\left(\mathrm{~N}^{3}\right), 3.37\left(\mathrm{~F}^{4}\right), 2.99\left(\mathrm{~F}^{7}\right), \sim 0.10 \\
\left(\mathrm{~N}^{\mathrm{NMe}}\right)\end{array}$ & $\begin{array}{c}5.40\left(\mathrm{~N}^{1}\right), 6.20\left(\mathrm{~N}^{3}\right), 5.73\left(\mathrm{~F}^{4}\right), 3.95\left(\mathrm{~F}^{7}\right),-0.20 \\
\left(\mathrm{~N}^{\mathrm{NMe2}}\right)\end{array}$ \\
\hline 8 & $\begin{array}{c}5.12\left(\mathrm{~N}^{1}\right), 5.73\left(\mathrm{~N}^{3}\right), 4.06\left(\mathrm{~F}^{4}\right), 3.39\left(\mathrm{~F}^{6}\right), 3.52\left(\mathrm{~F}^{7}\right) \\
0.11\left(\mathrm{~N}^{\mathrm{NMe} 2}\right)\end{array}$ & $\begin{array}{c}5.12\left(\mathrm{~N}^{1}\right), 6.31\left(\mathrm{~N}^{3}\right), 5.72\left(\mathrm{~F}^{4}\right), 1.43\left(\mathrm{~F}^{6}\right), 4.16\left(\mathrm{~F}^{7}\right), \\
-0.31\left(\mathrm{~N}^{\mathrm{NMe}}\right)\end{array}$ \\
\hline 9 & $5.49\left(\mathrm{~N}^{1,3}\right), 3.04\left(\mathrm{~F}^{4,7}\right), 0.18\left(\mathrm{~N}^{\mathrm{NMe} 2}\right)$ & $5.80\left(\mathrm{~N}^{1,3}\right), 4.95\left(\mathrm{~F}^{4,7}\right),-0.19\left(\mathrm{~N}^{\mathrm{NMe} 2}\right)$ \\
\hline $10^{c, d}$ & $4.92\left(\mathrm{~N}^{1}\right), 6.26\left(\mathrm{~N}^{3}\right), 5.94\left(\mathrm{~F}^{4}\right), 3.73\left(\mathrm{~F}^{6}\right)$ & $4.73\left(\mathrm{~N}^{1}\right), 6.21\left(\mathrm{~N}^{3}\right), 6.99\left(\mathrm{~F}^{4}\right), 2.89\left(\mathrm{~F}^{6}\right)$ \\
\hline 11 & $\begin{aligned} 5.44\left(\mathrm{~N}^{3}\right), 6.30\left(\mathrm{~N}^{1}\right), & 4.56\left(\mathrm{~F}^{4}\right), 2.94\left(\mathrm{~F}^{6}\right), 3.27\left(\mathrm{~F}^{7}\right) \\
& \sim 0.06(\mathrm{Cl})\end{aligned}$ & $5.30\left(\mathrm{~N}^{1}\right), 6.24\left(\mathrm{~N}^{3}\right), 5.58\left(\mathrm{~F}^{4}\right), 1.52\left(\mathrm{~F}^{6}\right), 3.82\left(\mathrm{~F}^{7}\right)$ \\
\hline 12 & $5.96\left(\mathrm{~N}^{1,3}\right), 4.37\left(\mathrm{~F}^{4,7}\right), 3.70\left(\mathrm{~F}^{5,6}\right)$ & $5.84\left(\mathrm{~N}^{1,3}\right), 3.36\left(\mathrm{~F}^{4,7}\right), 2.61\left(\mathrm{~F}^{5,6}\right)$ \\
\hline 13 & $5.90\left(\mathrm{~N}^{1}\right), 6.13\left(\mathrm{~N}^{3}\right), 4.04\left(\mathrm{~F}^{4}\right), 2.98\left(\mathrm{~F}^{6}\right), 3.25\left(\mathrm{~F}^{7}\right)$ & $5.58\left(N^{1}\right), 6.12\left(N^{3}\right), 4.40\left(F^{4}\right), 2.34\left(F^{6}\right), 3.61\left(F^{7}\right)$ \\
\hline 14 & $6.05\left(N^{1,3}\right), 2.06\left(F^{4,7}\right)$ & $5.83\left(\mathrm{~N}^{1,3}\right), 3.84\left(\mathrm{~F}^{4,7}\right)$ \\
\hline 15 & $5.964\left(N^{1,3}\right)$ & $5.69\left(N^{1,3}\right)$ \\
\hline 16 & $\begin{array}{c}5.73\left(\mathrm{~N}^{1}\right), 6.31\left(\mathrm{~N}^{3}\right), 3.66\left(\mathrm{~F}^{4}\right), 2.54\left(\mathrm{~F}^{6}\right), 3.27\left(\mathrm{~F}^{7}\right) \\
0.17\left(\mathrm{~N}^{\mathrm{NMe2}}\right)\end{array}$ & $\begin{array}{c}5.22\left(\mathrm{~N}^{1}\right), 6.40\left(\mathrm{~N}^{3}\right), 4.88\left(\mathrm{~F}^{4}\right), 1.80\left(\mathrm{~F}^{6}\right), 3.28\left(\mathrm{~F}^{7}\right) \\
-0.28\left(\mathrm{~N}^{\mathrm{NMe}}\right)\end{array}$ \\
\hline 17 & $6.04\left(\mathrm{~N}^{1,3}\right), 2.33\left(\mathrm{~F}^{4,7}\right), 0.20\left(2 \mathrm{~N}^{\mathrm{NMe} 2}\right)$ & $5.84\left(\mathrm{~N}^{1,3}\right), 4.01\left(\mathrm{~F}^{4,7}\right),-0.22\left(2 \mathrm{~N}^{\mathrm{NMe} 2}\right)$ \\
\hline 18 & $\begin{array}{c}5.68\left(\mathrm{~N}^{1}\right), 6.33\left(\mathrm{~N}^{3}\right), 3.57\left(\mathrm{~F}^{4}\right), 2.64\left(\mathrm{~F}^{6}\right), 3.45\left(\mathrm{~F}^{7}\right) \\
0.13\left(\mathrm{~N}^{\mathrm{NC4H80}}\right)\end{array}$ & $\begin{array}{c}5.21\left(\mathrm{~N}^{1}\right), 6.45\left(\mathrm{~N}^{3}\right), 5.48\left(\mathrm{~F}^{4}\right), 1.77\left(\mathrm{~F}^{6}\right), 3.22\left(\mathrm{~F}^{7}\right) \\
-0.23\left(\mathrm{~N}^{\mathrm{NC} 4 \mathrm{H} 80}\right)\end{array}$ \\
\hline 19 & $5.79\left(\mathrm{~N}^{1}\right), 6.23\left(\mathrm{~N}^{3}\right), 3.88\left(\mathrm{~F}^{4}\right), 2.61\left(\mathrm{~F}^{6}\right), 3.07\left(\mathrm{~F}^{7}\right)$ & $\begin{array}{c}5.17\left(\mathrm{~N}^{1}\right), 6.40\left(\mathrm{~N}^{3}\right), 5.02\left(\mathrm{~F}^{4}\right), 1.74\left(\mathrm{~F}^{6}\right), 3.27\left(\mathrm{~F}^{7}\right) \\
-0.33\left(\mathrm{~N}^{\mathrm{NC} 4 \mathrm{H} 8)}\right.\end{array}$ \\
\hline 20 & $\begin{array}{c}5.77\left(\mathrm{~N}^{1}\right), 5.34\left(\mathrm{~N}^{3}\right), 3.24\left(\mathrm{~F}^{4}\right), 0.67\left(\mathrm{~F}^{5}\right), 0.33\left(\mathrm{~F}^{6}\right) \\
2.41\left(\mathrm{~F}^{7}\right), 2.84\left(\mathrm{~F}^{8}\right), 2.82\left(\mathrm{~F}^{9}\right)\end{array}$ & $\begin{array}{c}5.34\left(\mathrm{~N}^{1}\right), 5.25\left(\mathrm{~N}^{3}\right), 4.39\left(\mathrm{~F}^{4}\right), 1.63\left(\mathrm{~F}^{5}\right),-0.69\left(\mathrm{~F}^{6}\right), \\
1.87\left(\mathrm{~F}^{7}\right), 3.23\left(\mathrm{~F}^{8}\right),-2.03\left(\mathrm{~F}^{9}\right)\end{array}$ \\
\hline $21^{e}$ & $6.09(N), 6.06(N), 4.35(F), 1.67(F), 1.56(F)$ & \\
\hline
\end{tabular}

a Numbers of RAs correspond to those of their neutral precursors; numbers of atoms $\mathrm{H}$ and $\mathrm{F}$ are the same as for $\mathrm{C}$ atoms they are bound with (Figure 1). ${ }^{\mathrm{b}}$ The EPR spectrum of RA 3 for MeCN was reported earlier. ${ }^{2 \mathrm{c}} \mathrm{HfC}$ constants with ${ }^{35,37} \mathrm{Cl}$ nuclei are small and result only inhomogeneous line broadening. ${ }^{d}$ EPR spectrum was simulated as a superposition of spectra of RA 10 (90\%) and RA of its 5-H congener from hydrodechlorination $(10 \%) ;$ hfs: $3 \mathrm{~N} \times 3 \mathrm{~N} \times 2 \mathrm{~F} \times 2 \mathrm{~F} \times 2 \mathrm{H} \times 4 \mathrm{Cl}$; hfc constants $(\mathrm{G}): a_{\mathrm{N}(1,3)}=6.42,4.53 ; a_{\mathrm{F}(4)}=4.92 ; a_{\mathrm{F}(6)}=2.06 ; a_{\mathrm{H}(5)}=1.16$; $a_{\mathrm{Cl}(7)} \approx 0.2$. ${ }^{\text {e RA }} 21$ was obtained from ECR defluorination of 12 (Scheme 2). 

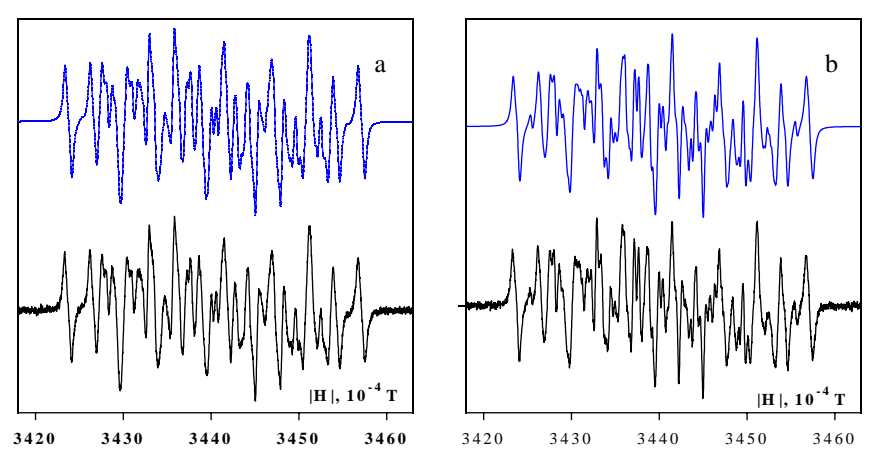

Figure 5. (a) The EPR spectrum of RA 2 in DMF and (b) its transformation when the stationary electrolysis potential is decreased to $E_{\mathrm{p}}^{2 \mathrm{C}}$.
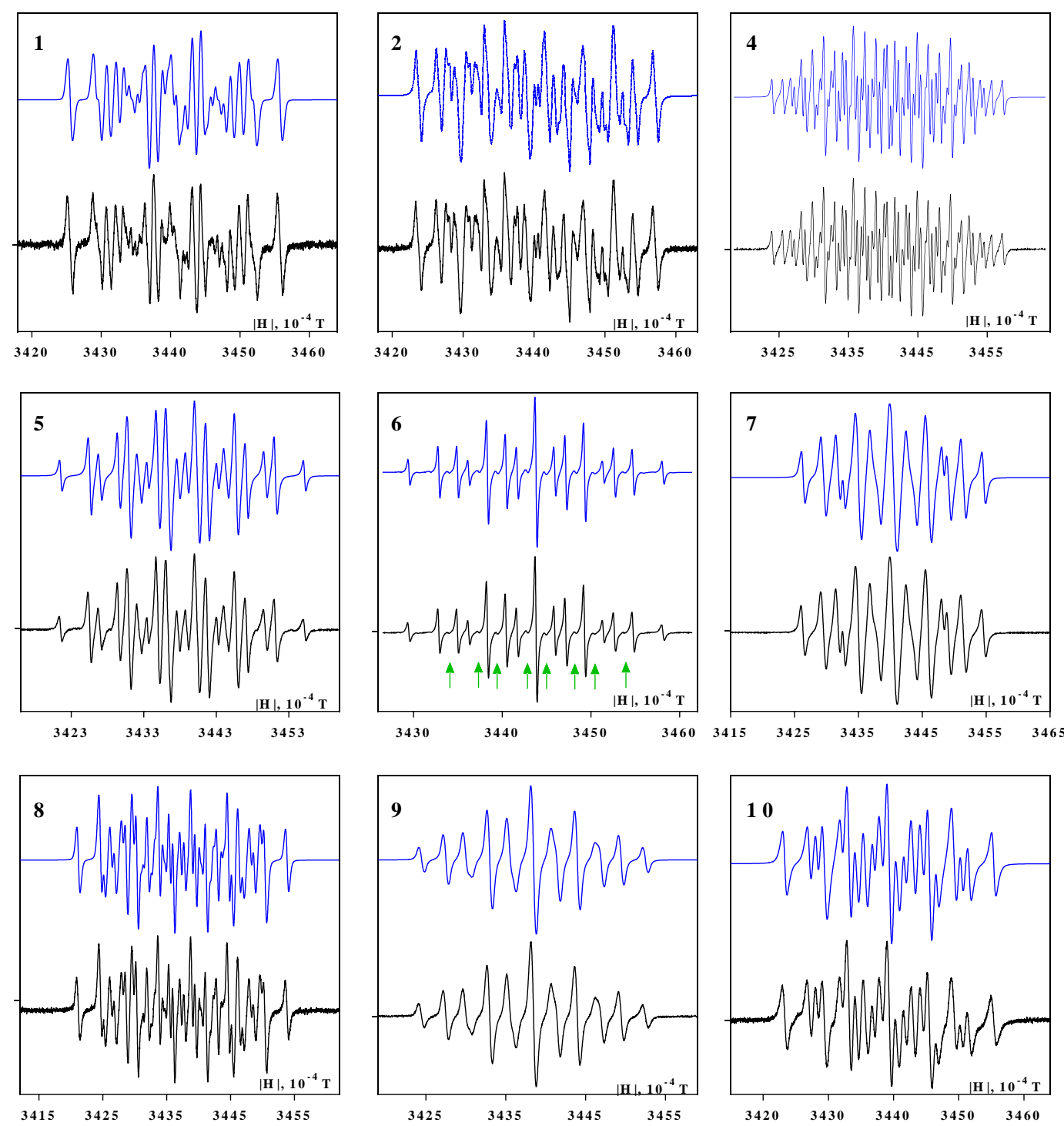

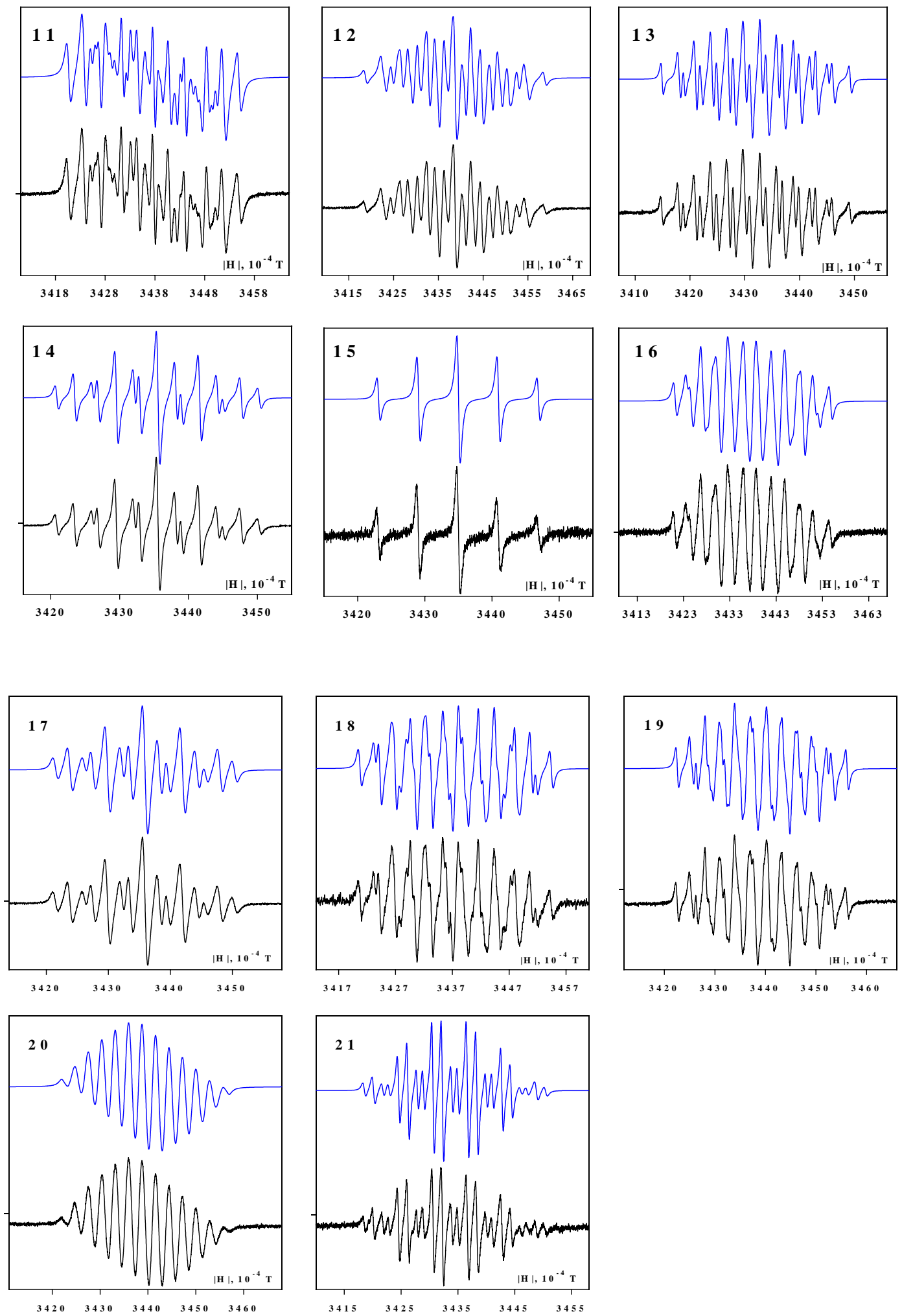

Figure 6. EPR spectra of RAs 1, 2 and 4-21 in DMF, experiment (black) and simulation (blue). For RA 6, green arrows indicate $\mathrm{hfs}$ from ${ }^{13} \mathrm{C}$ nuclei (the positions $3 \mathrm{a}, 4,7$ and $7 \mathrm{a}$ ) at their natural abundance. EPR spectrum of RA 21 was obtained under ECR of 12 at the potential of peak 2C (Figure 3); that of RA 3 in MeCN was reported. ${ }^{2}$ 
Except for 2 and 12, EPR spectra were measured under conventional conditions and attributed to primary RAs of the compounds. EPR spectrum of RA 2 (Figure 5, Table 2) was obtained with stationary electrolysis in the potential range $E_{\mathrm{p}}^{1 \mathrm{C}}>\mathrm{E}>-1.8 \mathrm{~V}$ (Figure 2); at the electrolysis potential decreased to $E_{\mathrm{p}}^{2 \mathrm{C}}$ or more, the spectrum was assigned as superposition of spectra of RAs 2 (90\%) and 4 (10\%). This proves the suggested two-electron mechanism of the hydrodechlorination of 2 in DMF with the participation of corresponding DA (Scheme 1). RAs of the other chlorine containing compounds 1, 10 and $\mathbf{1 1}$ (Table 2), possessing more positive EA $\mathrm{A}_{1}$ than 2 (Table 1), were much stable; in any way, their possible transformations associated with the dechlorination were not detected. Stationary electrolysis of $\mathbf{1 2}$ at the potential $E_{\mathrm{p}}^{\text {lc }}$ (Figure 3) resulted in its RA whose identity was confirmed by EPR and DFT (Figure 6, Table 2). The decrease of the potential to $E_{\mathrm{p}}^{2 \mathrm{C}}$ afforded RA 21 (Scheme 2; Figure 6, Table 2).

In some cases, the (U)B3LYP calculations overestimated Fermi-contact spin densities at ${ }^{19} \mathrm{~F}$ nuclei but practically quantitatively reproduced hfc constants with ${ }^{14} \mathrm{~N}$ nuclei (Table 2). According to the calculations, all RAs are planar as expected for the $\pi$-species (Figure 7, examples for RAs 2 and 11). Due to this, the hfc constants with ${ }^{35,37} \mathrm{Cl}$ nuclei are determined by spin-polarization mechanism of hyperfine interaction and, therefore, small in magnitude (Table 2, RAs 1, 2, 10 and 11).

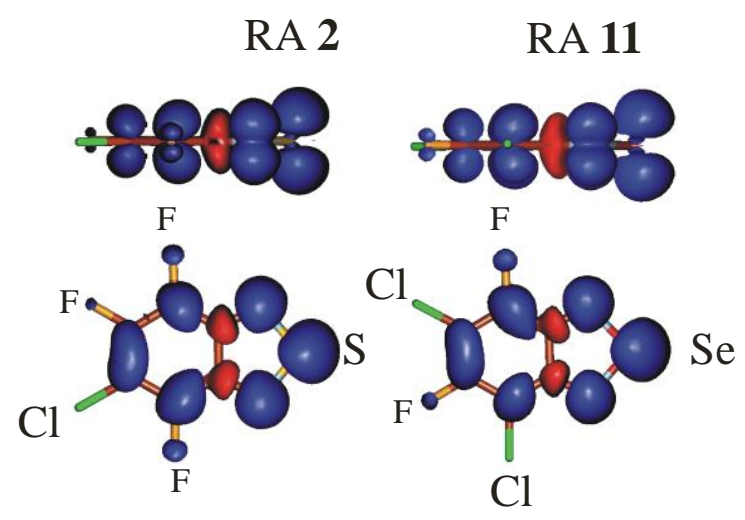

Figure 7. Spin density distributions in RAs $\mathbf{2}$ and $\mathbf{1 1}$ from the (U)B3LYP/6-31+G(d) calculations, color code: blue positive, red negative.

For RA 6, the most long-lived among the studied RAs, the hfs from ${ }^{13} \mathrm{C}$ nuclei was observed at their natural abundance (Figure 6). The resolved hfc constants with ${ }^{13} \mathrm{C}$ nuclei in the positions $3 \mathrm{a}, 4,7$ and $7 \mathrm{a}$ are practically equal, whereas those with nuclei in the positions 5 and 6 are small and not resolved. DFT suggests negative hfc constants with ${ }^{13} \mathrm{C}$ nuclei for the positions $3 \mathrm{a}$ and $7 \mathrm{a}$ and positive ones for the positions 4 and 7 for all studied RAs (for typical examples, see Figure 7). It should be noted that the hybrid functional B3LYP ca. 2.5 times overestimates Fermi-contact spin densities at ${ }^{13} \mathrm{C}$ nuclei, and that the calculated hfc constants with ${ }^{13} \mathrm{C}$ nuclei are almost equal which agrees with the experimental data (Table 2).

\section{Conclusions}

In DMF, the first stage of ECR of fluorinated/chlorinated 2,1,3-benzothia/selenadiazoles 1-20 (bearing also substituents $\mathrm{MeO}$ or $\mathrm{R}_{2} \mathrm{~N}$ ) is one-electron reversible process giving long-lived RAs whose authenticity is 
confirmed by EPR spectroscopy and DFT calculations at the (U)B3LYP/6-31+G(d) level of theory. The ECR firstpeak potentials correlate well with gas-phase calculated EAs forming independent linear regressions for $S$ and Se compounds. The potentials of selenadiazoles are less negative, and EAs more positive, than those of thiadiazoles; in contrast to the atomic EAs and Allen electronegativities, this suggests better electron-acceptor ability of Se derivatives which may be used in the design and synthesis of molecular functional materials.

At the second stage of ECR, hydrodechlorination of thia/selenadiazoles proceeds via corresponding DAs and their protonation. Non-hydrodefluorination of selenadiazoles at the same stage, involves reductive activation by two or more transferred electrons. These dehalogenations differ from those of related aromatics (benzenes, naphthalenes) ${ }^{35,36}$ and aza-aromatics (quinoxalines) ${ }^{32}$ controlled by instability of their RAs, and therefore are of interest to organic chemistry.

\section{Experimental Section}

General. ${ }^{1} \mathrm{H}(300.13 \mathrm{MHz})$ and ${ }^{19} \mathrm{~F}(282.36 \mathrm{MHz})$ NMR spectra were measured with Bruker AV-300 spectrometer for solutions in $\mathrm{CDCl}_{3}$; standards were $\mathrm{TMS}$ and $\mathrm{C}_{6} \mathrm{~F}_{6}\left(\delta^{19} \mathrm{~F}=-162.9\right.$ with respect to $\left.\mathrm{CFCl}_{3}\right)$. High-resolution $\mathrm{MS}$ spectra (EI, $70 \mathrm{eV})$ were obtained with DFS Thermo Electron instrument. UV-Vis spectra were collected with Varian Cary 5000, and fluorescence (FL) spectra with Varian Cary Eclipse, spectrophotometers, respectively, for solutions in heptane. Elemental analyses for $\mathrm{C}, \mathrm{H}$ and $\mathrm{N}$ were performed with Carlo Erba Model 1106 instrument, and those for $\mathrm{F}$ by standard spectrophotometric method with Ln complex of alizarin complexone. Studied compounds 1-17 and $\mathbf{2 0}$ were synthesized by known methods (Scheme 3) $29,30,37$ and compounds 18 and 19 in a similar way (below).

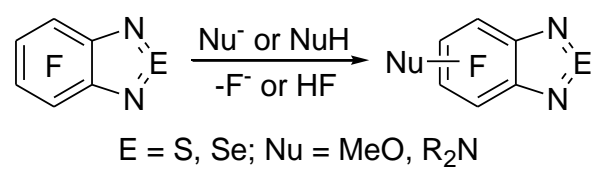

Scheme 3. Synthesis of non-chlorinated studied compounds by nucleophilic substitution of fluorine in the archetypal $3(\mathrm{E}=\mathrm{S})$ and $12(\mathrm{E}=\mathrm{Se})$. Chlorinated derivatives were prepared by cyclizing corresponding 1,2diaminobenzenes with $\mathrm{SOCl}_{2}$ or $\mathrm{SeO}_{2}{ }^{29,30,37}$

Cyclic voltammetry. The CV measurements on compounds 1-20 in DMF (1-2.6 mM solutions) were performed at $295 \mathrm{~K}$ in an argon atmosphere. The supporting electrolyte was $0.1 \mathrm{M} \mathrm{Et}_{4} \mathrm{NClO}_{4}$. A PG 310 USB potentiostat (HEKA Elektronik $\mathrm{GmbH}$, Germany) was used for the measurements. A standard electrochemical cell with solution volume of $5 \mathrm{ml}$ connected to the potentiostat with a three-electrode scheme was employed. A stationary Pt electrode $\left(S=0.064 \mathrm{~cm}^{2}\right)$ was used as a working electrode, and Pt helix as an auxiliary electrode. Peak potentials were quoted with reference to a saturated calomel electrode (SCE). The potential sweep rates were $0.05-1.3 \mathrm{~V} \cdot \mathrm{s}^{-1}$.

EPR spectroscopy. The EPR spectra of RAs were recorded with an ELEXSYS E-540 spectrometer (X-band, MW frequency $\sim 9.87 \mathrm{GHz}$, MW power $1 \mathrm{~mW}$, modulation frequency $100 \mathrm{kHz}$, and modulation amplitude $0.006 \mathrm{mT}$ ) equipped with a high-Q cylindrical resonator ER4119HS. For the EPR measurements, stationary ECR of compounds 1-20 at corresponding potentials of the first reduction peaks was carried out at $295 \mathrm{~K}$ under anaerobic conditions. Electrochemical cell for EPR measurements equipped with Pt working electrode was placed into the EPR cavity. Electrolysis was performed in a dry DMF with $0.1 \mathrm{M} \mathrm{Et}_{4} \mathrm{NClO}_{4}$ as a supporting 
electrolyte. Simulations of the experimental EPR spectra were accomplished with the Winsim 2002 program. ${ }^{38}$ The Simplex algorithm was used for optimization of hfc constants and line widths.

DFT calculations. The DFT calculations on compounds 1-20 and their RAs were performed with full geometry optimization at the $(U) B 3 L Y P / 6-31+G(d)$ level of theory using the GAMESS program. ${ }^{39}$ For all studied RAs the value $S^{2}$ did not exceed 0.76 .

5-(Morpholin-4-yl)-4,6,7-trifluoro-2,1,3-benzoselenadiazole (18). Stirred solution of $100 \mathrm{mg}(0.39 \mathrm{mmol})$ of 12 and $86 \mathrm{mg}(0.39 \mathrm{mmol})$ of morpholine in $6 \mathrm{ml}$ of toluene was kept at $70{ }^{\circ} \mathrm{C}$ for $12 \mathrm{~h}$, cooled to ambient temperature and passed through silica column, eluent toluene. The eluate was evaporated under reduced pressure, and the residue recrystallized from 2:1 hexane / toluene. Compound 18 was obtained in the form of yellow crystals, yield $82 \mathrm{mg}(65 \%), \mathrm{mp} 234-235{ }^{\circ} \mathrm{C}$. Elemental analysis for $\mathrm{C}_{10} \mathrm{H}_{8} \mathrm{~F}_{3} \mathrm{~N}_{3} \mathrm{OSe}(\%)$ : found: 37.74 (C); $2.18(\mathrm{H}) ; 12.89(\mathrm{~N})$; $17.24(\mathrm{~F})$; calculated: $37.28(\mathrm{C}) ; 2.50(\mathrm{H}) ; 13.04(\mathrm{~N}) ; 17.69(\mathrm{~F}) . \mathrm{MS}, \mathrm{m} / z: 322.9776$ $\left[\mathrm{C}_{10} \mathrm{H}_{8} \mathrm{~F}_{3} \mathrm{~N}_{3} \mathrm{O}^{80} \mathrm{Se}\right]^{+}$(calculated 322.9779). NMR (ESI, Figure S3), $\delta:{ }^{1} \mathrm{H}: 3.22(\mathrm{~m}, 4 \mathrm{H}), 3.84(\mathrm{~m}, 4 \mathrm{H}) ;{ }^{19} \mathrm{~F}: 22.1(\mathrm{~d}, \mathrm{~F}-$ 4, J $19 \mathrm{~Hz}$ ), 19.8 (d, F-6, J 13.8 Hz), 11.1 (dd, F-7, J 19, J 13.8 Hz). UV-Vis, $\lambda_{\max }, \mathrm{nm}$, (log $\left.\varepsilon\right): 326$ (4.12). FL, $\lambda_{\max }\left(\lambda_{\text {ex }}\right)$, $\mathrm{nm}: 454$ (372).

5-(Pyrrolidin-1-yl)-4,6,7-trifluoro-2,1,3-benzoselenadiazole (19). Stirred solution of $100 \mathrm{mg}(0.39 \mathrm{mmol})$ of 12 and $28 \mathrm{mg}(0.39 \mathrm{mmol})$ of pyrrolidine in $5 \mathrm{ml}$ of toluene was kept at $65{ }^{\circ} \mathrm{C}$ for $15 \mathrm{~h}$, cooled to ambient temperature and passed through silica column, eluent toluene. The eluate was evaporated under reduced pressure, and the residue recrystallized from $5 \mathrm{ml}$ of toluene. Compound 19 was obtained in the form of yellow crystals, yield $89 \mathrm{mg}(74 \%), \mathrm{mp} 178-179{ }^{\circ} \mathrm{C}$. Elemental analysis for $\mathrm{C}_{10} \mathrm{H}_{8} \mathrm{~F}_{3} \mathrm{~N}_{3} \mathrm{Se}$ (\%): found: $38.99(\mathrm{C}) ; 2.59(\mathrm{H})$; $13.48(\mathrm{~N}) ; 18.87(\mathrm{~F})$; calculated: $39.23(\mathrm{C}) ; 2.63(\mathrm{H}) ; 13.73(\mathrm{~N}) ; 18.62(\mathrm{~F}) . \mathrm{MS}, \mathrm{m} / z$ : $306.9831\left[\mathrm{C}_{10} \mathrm{H}_{8} \mathrm{~F}_{3} \mathrm{~N}_{3}{ }^{80} \mathrm{Se}^{+}\right.$ (calculated 306.9830). NMR (ESI, Figure S4), $\delta:{ }^{1} \mathrm{H}: 1.96(\mathrm{~m}, 4 \mathrm{H}), 3.71(\mathrm{~m}, 4 \mathrm{H}) ;{ }^{19} \mathrm{~F}: 21.6(\mathrm{~m}, \mathrm{~F}-4), 14.2(\mathrm{~m}, \mathrm{~F}-6)$, 10.2 (dd, F-7; J 16.8, J 12.1 Hz). UV-Vis, $\lambda_{\max }(\log \varepsilon)$ : 258 (4.11), 340 (3.86), 444 (3.70). FL, $\lambda_{\max }\left(\lambda_{\text {ex }}\right), \mathrm{nm}: 510$ (445). Interaction of 12 with $\mathrm{KOH}$ in DMF. At ambient temperature, a stirred solution of $100 \mathrm{mg}(0.39 \mathrm{mmol})$ of 12 and $22.4 \mathrm{mg}(0.39 \mathrm{mmol})$ of $\mathrm{KOH}$ in $5 \mathrm{ml}$ of DMF was kept for $72 \mathrm{~h}$. Despite dark color of the reaction mixture, NMR revealed only starting $12\left(\delta^{19} \mathrm{~F}: 13.0,5.6\right)$. After $8 \mathrm{~h}$ at $80^{\circ} \mathrm{C}$, compound $16^{28}$ (i.e. product of substitution of $\mathrm{F}$ with $\mathrm{Me}_{2} \mathrm{NH}$ from decomposition of DMF) was detected $\left(\delta^{19} \mathrm{~F}: 21.7,19,7,10.2\right)$ together compound 12; product of the substitution with $\mathrm{HO}^{-}$was not observed.

\section{Acknowledgements}

The authors are grateful to the Multi-Access Center Chemical Service, Siberian Branch of the Russian Academy of Sciences, for instrumental facilities.

\section{Supplementary Material}

See Figure S1. Linear dependences $I_{\mathrm{p}}^{1 \mathrm{C}}$ vs. $v^{1 / 2}$ proving diffusion-controlled nature of the first peaks of ECR of 1, 2 and 4-20. Table S1. Parameters of linear regressions $I_{\mathrm{p}}^{1 \mathrm{C}}=A \cdot v^{1 / 2}+B$ for $\mathbf{1 ,} 2$ and 4-20 . Figure S2. CVs of 1, 4-10 and 13-20 at different potential sweep rates. Figure S3. NMR spectra of the compound 18. Figure S4. NMR spectra of the compound 19.

\section{References}


1. Boere, R. T.; Roemmele, T. L. Coord. Chem. Rev. 2000, 210, 369-445.

https://doi.org/10.1016/S0010-8545(00)00349-0

2. Vasilieva, N. V.; Irtegova, I. G.; Gritsan, N. P.; Lonchakov, A. V.; Makarov, A. Yu.; Shundrin, L. A.; Zibarev, A. V. J. Phys. Org. Chem. 2010, 23, 536-543.

https://doi.org/10.1002/poc.1637

3. Lonchalov, A. V.; Rakitin, O. A.; Gritsan, N. P.; Zibarev, A. V. Molecules 2013, 18, 9850-9900. https://doi.org/10.3390/molecules 18089850

4. Neto, B. A. D.; Lapis, A. A. M.; de Silva Junior, E. N.; Dupont, J. Eur. J. Org. Chem. 2013, 2013, $228-255$. https://doi.org/10.1002/ejoc.201201161

5. Todress, Z. V. Chalcogenadiazoles: Chemistry and Applications. CCR Press / Taylor \& Francis: London, 2012.

6. Koutentis, P. A. Comprehensive Heterocyclic Chemistry III. Eds. Katritzky, A. R.; Ramsden, C. A.; Scriven, E. F. V.; Taylor, R. J. K.; Elsevier: Oxford, 2008; Vol. 5, pp 516-564.

7. Koutentis, P. A. Science of Synthesis. Eds. Storr, R. C.; Gilchrist, T. L.; Thieme: Stuttgart, 2003; Vol. 13, pp 297-348.

8. Semenov, N. A.; Bagryanskaya, I. V.; Alekseev, A. V.; Gatilov, Yu. V.; Lork, E.; Mews, R.; Roeschentaler G.V.; Zibarev A. V. J. Struct. Chem. 2010, 51, 552-557.

https://doi.org/10.1007/s10947-010-0080-5

9. Bashirov, D. A.; Sukhikh, T. S.; Kuratieva, N. V.; Chulanova, E. A.; Yushina, I. V.; Gritsan, N. P.; Konchenko, S. N.; Zibarev A. V. RSC Advances 2014, 4, 28309-28316.

https://doi.org/10.1039/c4ra03342f

10. Bashirov, D. A.; Sukhikh, T. S.; Kuratieva, N V.; Naumov, D. Yu.; Konchenko, S. N.; Semenov, N. A.; Zibarev, A. V. Polyhedron 2012, 42, 168-174.

https://doi.org/10.1016/i.poly.2012.05.015

11. Konchenko, S. N.; Gritsan, N. P.; Lonchakov, A. V.; Radius, U.; Zibarev, A.V. Mendeleev Commun. 2009, 19, 7-9.

https://doi.org/10.1016/j.mencom.2009.01.003

12. Semenov, N. A.; Pushkarevsky, N. A.; Suturina, E. A.; Chulanova, E. A.; Kuratieva, N. V.; Bogomyakov, A. S.; Irtegova, I.G.; Vasilieva, N. V.; Konstantinova, L. S.; Gritsan N. P.; Rakitin, O. A.; Ovcharenko, V. I.; Konchenko, S. N.; Zibarev, A. V. Inorg. Chem. 2013, 52, 6654-6663.

https://doi.org/10.1021/ic400659q

13. Zhang, X.; Bronstein, H.; Kronemeijer, A. J.; Smith, J.; Kim, Y.; Kline, R. J.; Richter, L. J.; Antopoulos, T. D.; Sirringhaus, H.; Song, K.; Heeney, M.; Zhang, W.; McCulloch, I.; DeLongchamp, D. M. Nature Commun. 2013, 4, 2238.

14. Tsao, H. N.; Cho, D. M.; Park, I.; Hansen, M. R.; Mavrinsky, A.; Yoon, D. Y.; Graf, R.; Pisula, W.; Spiess, H. W.; Muellen, K. J. Am. Chem. Soc. 2011, 133, 2605-2612.

https://doi.org/10.1021/ja108861q

15. Nielsen, C. B.; Schoeder, B. C.; Hadipour, A.; Rand, B. P.; Watkins, S. E.; McCulloch, I. J. Mater. Chem. 2011, 21, 17642-17645.

https://doi.org/10.1039/c1jm13393d

16. Mancilha, P. S.; Barloy, L.; Rodembusch, F. S.; Dupont, J.; Pfeffer, M. Dalton Trans. 2011, 40, 10535-10544. https://doi.org/10.1039/c1dt10666j

17. Thomas, K. R. J.; Lin, J. T.; Velusamy, M.; Tsao, Y. T.; Chuen, C. H. Adv. Funct. Mater. 2004, 14, 83-90. https://doi.org/10.1002/adfm.200304486 
18. Zang, X.; Gorohmaru, H.; Kadowaki, M.; Kobayashi, T.; Ishii, T.; Tiemann, T.; Mataka, S. J. Mater. Chem. 2004, 14, 1901-1904.

https://doi.org/10.1039/B402645D

19. Hou, Q.; Zhou, Q.; Zhang, Y.; Yang, W.; Yang, R.; Cao, Y. Macromolecules 2004, 37, 6299-6305. https://doi.org/10.1021/ma049204g

20. Liu, J.; Zhou, Q. G.; Cheng, Y. X.; Geng, Y. H.; Wang, L. X.; Ma, D. G.; Jing, X. B.; Wang, R. S. Adv. Funct. Mater. 2006, 16, 957-965.

https://doi.org/10.1002/adfm.200500761

21. Uchiyama, S.; Kimura, K.; Gota, C.; Okabe, K.; Kawamoto, K.; Inada, N.; Yoshihara, T.; Tobita, S. Chem. Eur. J. 2012, 18, 9552-9563.

https://doi.org/10.1002/chem.201200597

22. Neto, B. A. D.; Carvalho, P. H. P. R.; Correa, J. R. Acc. Chem. Res. 2015, 48, 1560-1569. https://doi.org/10.1021/ar500468p

23. Sukhikh, T. S.; Bashirov, D. A.; Ogienko, D. S.; Kuratieva, N. V.; Sherin, P. S.; Rakhmanova, M. I.; Chulanova, E. A.; Gritsan, N. P.; Konchenko S. N.; Zibarev, A. V. RSC Advances, 2016, 6, 43901-43910. https://doi.org/10.1039/C6RA06547C

24. Sukhikh, T. S.; Bashirov, D. A.; Kuratieva, N. V.; Smolentsev, A. I.; Bogomyakov, A. S.; Burilov, V. A.; Mustafina, A. R.; Zibarev, A. V.; Konchenko, S. N. Dalton Trans. 2015, 44, 5727-5734. https://doi.org/10.1039/C4DT03878A

25. Sukhikh, T. S.; Bashirov, D. A.; Kolybalov, D. S.; Andreeva, A. Yu.; Smolentsev, A. I.; Kuratieva, N. V.; Burilov, V. A.; Mustafina, A. R.; Kozlova, S. G.; Konchenko, S. N. Polyhedron 2017, 124, 139-144.

https://doi.org/10.1016/i.poly.2016.12.041

26. Babudri, F.; Farinola, G. M.; Naso, F.; Ragni, R. Chem. Commun. 2007, 1003-1022. https://doi.org/10.1039/B611336B

27. Nielsen, C. B.; White, A. J. P.; McCulloch, J. J. Org. Chem. 2015, 80, 5045-5048. https://doi.org/10.1021/acs.joc.5b00430

28. Wu, J. I.; Puehlhofer, F. G.; von Rague Schleyer, P.; Puchta, R.; Kiran, B.; Mauksch M.; van Eikema Hommes, N. J. R.; Alkorta, I.; Elguero, J. J. Phys. Chem. A 2009, 113, 6789-6794.

https://doi.org/10.1021/jp902983r

29. Mikhailovskaya, T. F.; Makarov A. G.; Selikhova N. Yu.; Makarov, A. Yu.; Pritchina, E. A.; Bagryanskaya, I. Yu.; Vorontsova, E. V.; Ivanov, I. D.; Tikhova, V. D.; Gritsan N. P.; Slizhov Yu. G.; Zibarev, A. V. J. Fluorine Chem. 2016, 183, 44-58.

https://doi.org/10.1016/i.jfluchem.2016.01.009

30. Makarov, A. G.; Selikhova, N. Yu.; Makarov, A. Yu.; Malkov, V. S.; Bagryanskaya, I. Yu.; Gatilov, Yu. V.; Knyazev, A. S.; Slizhov, Yu. G.; Zibarev, A. V. J. Fluorine Chem. 2014, 165, 123-131.

https://doi.org/10.1016/j.jfluchem.2014.06.019

31. Organic Redox Systems: Synthesis, Properties, and Applications. Ed. Nishinaga, T.; Wiley, 2016.

32. Shundrin, L. A.; Vasilieva, N. V.; Irtegova, I. G.; Avrorov, P. A.; Selikhova, N. Yu.; Makarov, A. G.; Makarov, A. Yu.; Slizhov, Yu. G.; Zibarev, A. V. J. Phys. Org. Chem. 2017.

https://doi.org/10.1002/poc.3667

33. Konstantinova, L. S.; Knyazeva, E. A.; Obruchnikova, N. V.; Vasilieva, N. V.; Irtegova, I. G.; Nelyubina, Yu. V.; Bagryanskaya, I. Yu.; Shundrin, L. A.; Zibarev, A. V.; Rakitin, O. A. Tetrahedron 2014, 70, 5558-5568. https://doi.org/10.1016/j.tet.2014.06.096 
34. Dunyashev, V. S.; Polenov, E. A.; Minina, N. E.; Kazakova, V. M.; Grigorev, G. A.; Yagupolskii, L. M. Zh. Obshch. Khim. (Russ. J. Gen. Chem.) 1988, 58, 200-201 (in Russian).

35. Rossi, R. A.; Pierini, A. B.; Penenory, A. B. Chem. Rev. 2003, 103, 71-167. https://doi.org/10.1021/cr9601340

36. Saveant, J. M. Acc. Chem. Res. 1980, 13, 323-329. https://doi.org/10.1021/ar50153a005

37. Zibarev, A. V.; Miller, A. O. J. Fluorine Chem. 1990, 50, 359-363. https://doi.org/10.1016/S0022-1139(00)85001-0

38. R. D. Duling, J. Magn. Reson. 1994, 104, 105-115. https://doi.org/10.1006/jmrb.1994.1062

39. Schmidt, M. W.; Baldridge, K. K.; Boatz, J. A.; Elbert, S. T.; Gordon, M. S.; Jensen, J. H.; Koseki, S.; Matsunaga, N.; Nguyen, K. A.; Su, S. J.; Windus, T. L.; Dupuis, M.; Montgomery, J. A. J. Comput. Chem. 1993, 14, 13471363.

https://doi.org/10.1002/jcc.540141112 